\title{
Study the Molar Ratio of the Reaction between Thalassemia s Drug (Deferoxamine) with Iron Over loud
}

\author{
Amer Hasan Abdullah \\ Department of Chemistry, College of Science Al-Mustansiriya University, Baghdad-Iraq. \\ E-mail: amerhasan1965@yahoo.com.
}

\begin{abstract}
Iron-Deferoxamine complex have been synthesized in vitro by the reaction of deferoxamine (which are use as therapeutic agent for removing iron overload from the bodies of thalassemia patients) with $\mathrm{Fe}$ (II) salt in aqueous medium. The geometry of the prepared complex as well as the mode of bonding were determined through FTIR, UV-Vis, mass spectral studies, metal content, and molar conductance. These studies revealed octahedral geometry for the complex with the general formula $\left[\mathrm{Fe}^{\mathrm{II}}(\mathrm{DEF})\right] \mathrm{Cl}_{2}$. Complex formation via molar ratio method and variation continuous method in aqueous solution have been also investigated and results were consistent to those found in the solid complexes with a ratio of $(\mathrm{M}: \mathrm{L})$ as $(1: 1)$. Conditional formation constant could also be calculated for $\left[\mathrm{Fe}^{\mathrm{II}}(\mathrm{DEF})\right] \mathrm{Cl}_{2}$ as $2.0 \times 10^{3}$. The effect of time on the formation of Iron Deferoxamine complex has been also studied. This study showed that each $1 \times 10^{-3} \mathrm{M}$ of deferoxamine needs $2.5-3 \mathrm{hrs}$ to remove $1 \times 10^{-3} \mathrm{M}$ of Iron (II) by formation coordination complex.
\end{abstract}

Keywords: Thalassemia, Deferoxamine, Iron Over loud.

\section{Introduction}

Iron is stored in the body in the form of the protein complexes, ferritin and hemosiderin, and is transported in the plasma via the protein complex, transferring[1]. It has been estimated that, under normal physiological conditions, about a third to a half of transferrin's iron capacity is utilized. The excess of iron leads to saturation of the transferrin and ferritin and results in toxicity as the iron overloud levels the bloodstream and accumulates in tissues. In principle, this condition can be treated by administration of some of iron chelating agent remobilizes iron and permits its excretion [2].

Hydroxamic acids repersent one of the most important organic bioligands. Firstly the physiological role of these weak acids was used as siderophores by microorganisms $[3,4]$. Nevertheless, siderophores are also used as pharmacological and agrochemical agents in addition to it uses in clinical therapy, in the sequestration or scavenging of metallic ions [5]. Deferoxamine is an example of hydroxamic siderophore that employed in the treatment of patients constantly submitted to blood transfusion. Iron accumulation in these cases can reach toxic. Deferoxamine administration is an effective way to remove iron excess by water soluble complex formation that is eliminated through bile or urine [6,7]. In general, hydroxamic siderophores may be considered in infection treatment, such as malaria, tuberculosis, leprosy and cholera due to ability to access infected cells and remove iron from intracellular parasites. In this paper, IronDeferoxamine complex has been synthesized in vitro by the reaction of deferoxamine with $\mathrm{Fe}$ (II) salt in aqueous medium. The mode of bonding and geometry of the prepared complex were determined by used different techniques FTIR, UV-Vis, mass spectral studies, metal content, and molar conductance. Complex formation via molar ratio method and variation continuous method in aqueous solution have been also investigated and the formation constant of the complex has been calculated.

\section{Experimental \\ Materials and Measurements}

All reagents were commercially available (Aldrich Co.) and used without further purification. All manipulations in the synthesis of $\left[\mathrm{Fe}^{\mathrm{II}}(\mathrm{DEF})\right] \mathrm{Cl}_{2}$ was performed under air. Electronic spectra were measured in the region (200-900) $\mathrm{nm}$ for solutions in distilled water at room temperature using a Shimadzu, 100 UV-visible spectrophotometer. Infrared spectra were recorded using a Shimadzu 8400 FTIR 
spectrophotometer. Mass spectrum was recorded using Waters 996 Micromass. Conductivity measurements were made with distilled water solution using a Jenway 4071 digital conductivity meter.

\section{Synthesis of $[\mathrm{Fe}(\mathrm{DEF})] \mathrm{Cl}_{2}$}

To a solution of deferoxamine $\left(5.6 \times 10^{-3} \mathrm{~g}\right.$, $0.01 \mathrm{mmol}$ ) in $10 \mathrm{ml}$ distilled water was added the solution of $\mathrm{FeCl}_{2} \cdot \mathrm{XH}_{2} \mathrm{O}\left(1.27 \times 10^{-3} \mathrm{~g}\right.$, $0.01 \mathrm{mmol}$ ) in $10 \mathrm{ml}$ distilled water. The solution was not stirred and left undisturbed overnight. The complex was obtained by slow evaporation of solvent at room temperature. Yield 87\%, m.p $=100 \mathrm{C}^{\circ}$.

\section{Molar Ratio}

Complex formation by molar ratio of Deferoxamine to $\mathrm{Fe}(\mathrm{II})$ was studied in distilled water. A series of solutions containing constant concentration of $\mathrm{Fe}(\mathrm{II})\left(10^{-3} \mathrm{M}\right)$ was treated with the same volumes of various concentrations of Deferoxamine. The results of L: $M$ titrations were obtained by plotting the correct absorbance of solution mixtures at $430 \mathrm{~nm}$ of the complex against [L]/[M].

\section{Continuous Variation Method}

Complex formation by continuous variation method was also studied in distilled water. A series of solutions was prepared, each containing the same total number of moles of deferoxamine and $\mathrm{Fe}(\mathrm{II})$, but a different ratio of $\mathrm{Fe}$ (II) moles to deferoxamine moles. The results of L: $M$ titrations were obtained by plotting the correct absorbance of solution mixtures at $430 \mathrm{~nm}$ of the complex against $\mathrm{V}_{\mathrm{Fe}(\mathrm{II})} / \mathrm{V}_{\mathrm{Fe}(\mathrm{II})}+\mathrm{V}_{\mathrm{DEF}}$.

\section{Result and Discussion}

Deferoxamine is a trihydroxamic siderophore with a terminal primary amine group (Scheme (1)).

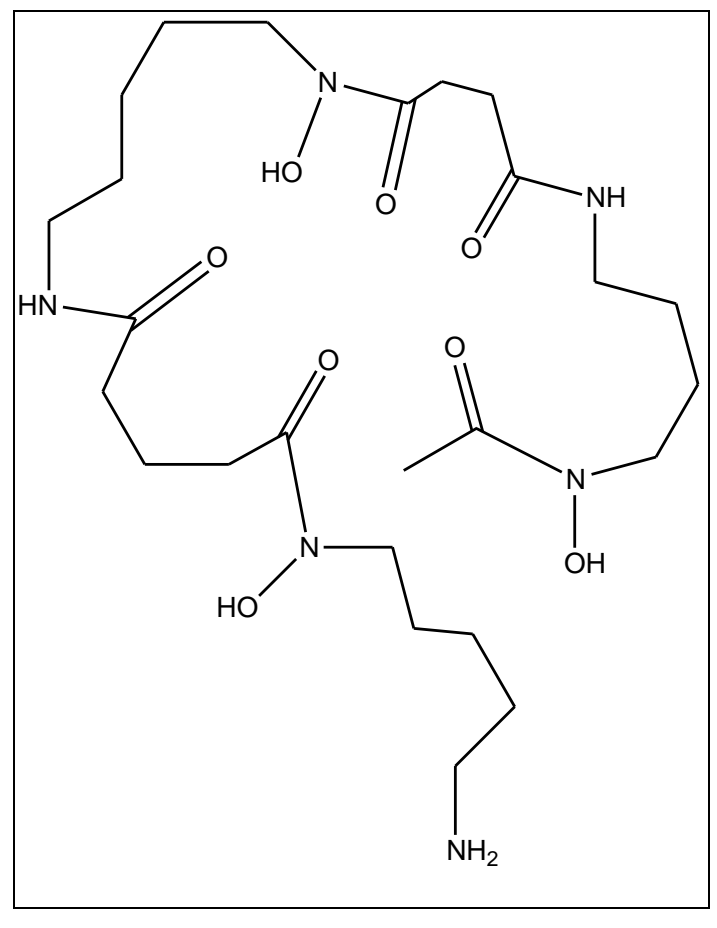

\section{Scheme (1): General structural formulae of Deferoxamine.}

It has medical applications as a chelating agent used to remove iron loud from the body [8]. Deferoxamine is used to treat acute iron poisoning in small children. This agent is usually frequently used to treat hemochromatosis, a disease of iron accumulation that can be both genetic and acquired hemochromatosis is common in patients with types of chronic anemia (e.g. thalassemia and myelodysplastic syndrome) who require a blood transfusions, which can increase the amount of iron in the body [9]. Administration for chronic conditions is basically accomplished by subcutaneous injection (SQ) over a period of 8-12 hours daily. The effect of deferoxamine after acute intoxication may color the urine a pinkish red, a phenomenon termed "vin rose urine".

\section{Synthesis of Iron - Deferoxamine Complex \\ Iron-Defroxamine complex was synthesized by the reaction of equimolar amounts of Deferoxamine and $\mathrm{FeCl}_{2} \cdot \mathrm{XH}_{2} \mathrm{O}$ in aqueous media under nitrogen atmosphere. Complex with general formulae $[\mathrm{Fe} \mathrm{DEF}] \mathrm{Cl}_{2}$ was obtained, (Scheme (2)).}






Scheme (2): Proposed structure of Iron Deferoxamine complex.

Despite numerous attempts, have been unable to obtain crystals suitable for x-ray structural diffraction. The complex is soluble in water and other common organic solvents. Deferoxamine has a high selectivity for Fe(III) may be explained by the principle of hard and soft Lewis acid and base, where acids are electron acceptor atoms and bases are the electron donor ones in a chemical bound. Hard acids (small, compact and scarcely polarizable atoms), like $\mathrm{Fe}(\mathrm{III})$, present high affinity for hard bases, like oxygen. Therefore, deferoxamine complexes present different stabilities depending upon the hardness of the metal. The highest affinity of $\mathrm{Fe}$ (III) for deferoxamine can be also explained by $d$ electron configuration, high charge density and high electronegativity presented by this ion $[5,10]$. The carbonic chain length and the structure that connects the hydroxamic groups as well as the number of chelating groups also affect complex stability $[11,12]$.

\section{Characterization of Iron-Deferoxamine complex}

The complex was characterized by different techniques (FTIR spectrophotometer, UV-Vis spectrophotometer, Mass spectrophotometer, Atomic absorption spectrophotometer, Molar conductivity, Magnetic Susceptibility). The analytical data agree well with the suggested formulae. The positive (EI) mass spectrum of the complex, Fig.(1) showed the parent ion peak at $\mathrm{m} / \mathrm{z} 688$ corresponding to $(\mathrm{M}+)$. The FTIR spectrum exhibited band at $3313 \mathrm{~cm}^{-1}$, which is assigned to $v(\mathrm{NH})$ vibration. The bands due to $v(\mathrm{C}-\mathrm{H})$ and $v(\mathrm{C}=\mathrm{O})$ vibrations are located in the regions 2931 and $1626 \mathrm{~cm}^{-1}$, respectively [13]. At far infrared region the complex showed band at $530 \mathrm{~cm}^{-1}$, which could be assigned to the vibration of $v(\mathrm{Fe}-\mathrm{O})$ [14]. The UV - Vis spectrum of deferoxamine displayed an intense absorption peak related to the $\left(\pi-\pi^{*}\right)$ transition, at $48543 \mathrm{~cm}^{-1}$. The $\left(\mathrm{n}-\pi^{*}\right)$ transition may be obscured by this absorption band, Fig.(2). The electronic spectrum of Iron - Deferoxamine complex showed the $\left(\pi-\pi^{*}\right)$ transition at $47846 \mathrm{~cm}^{-1}$. The spectrum also displayed abroad band around $\left(18181-30303 \mathrm{~cm}^{-1}\right)$ which could be attributed to CT and spin allowed transition in octahedral geometry, $\left({ }^{5} \mathrm{~T}_{2} \mathrm{~g}-{ }^{5} \mathrm{~A}_{1} \mathrm{~g}\right)$ and $\left({ }^{5} \mathrm{~T}_{2} \mathrm{~g}-{ }^{5} \mathrm{Eg}\right)[15-17]$. The molar conductivity of the complex is $235 \mathrm{~S} \mathrm{~cm}^{2} \mathrm{~mol}^{-1}$. This value indicates the electrolytic nature of IronDeferoxamine complex [18].

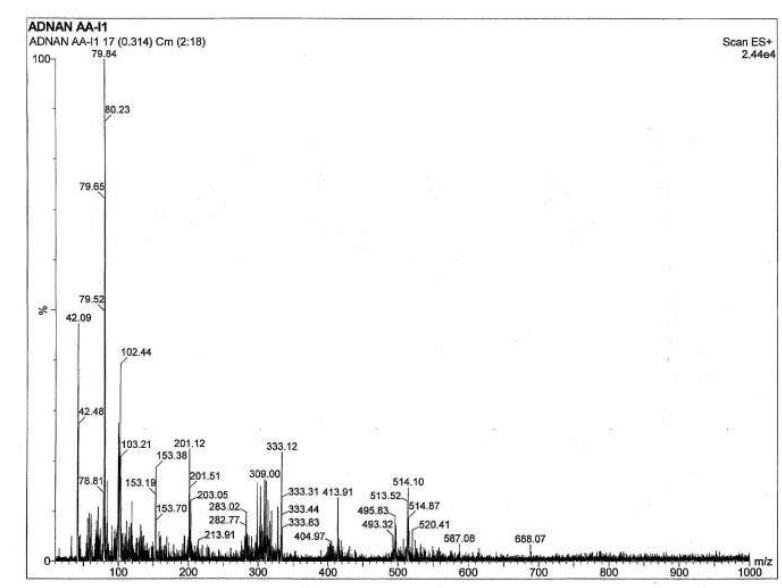

Fig.(1): Mass spectrum of Iron Deferoxamine complex.

\section{Continuous Variation Method}

The method of Continuous variations has been used frequently to determine the formulas and formation constants of complexes since its introduction by Ostromisslensky [19] and Job [20]. The method is based on plotting measured absorbances, corrected for absorbances of reactants assuming no complexation, against mole fractions of the two constituents of a complex. Thus, a series of solutions is prepared by mixing different volumes of equimolar solutions of 
deferoxamine and $\mathrm{Fe}(\mathrm{II})$ and diluting to a constant volume to give solutions having identical total molar concentrations but different mole fractions. Firstly deferoxamine's and $\mathrm{Fe}$ (II) electronic spectra were acquired in order to evaluate the best wavelength to perform the complex absorbance measurements Fig.(2).

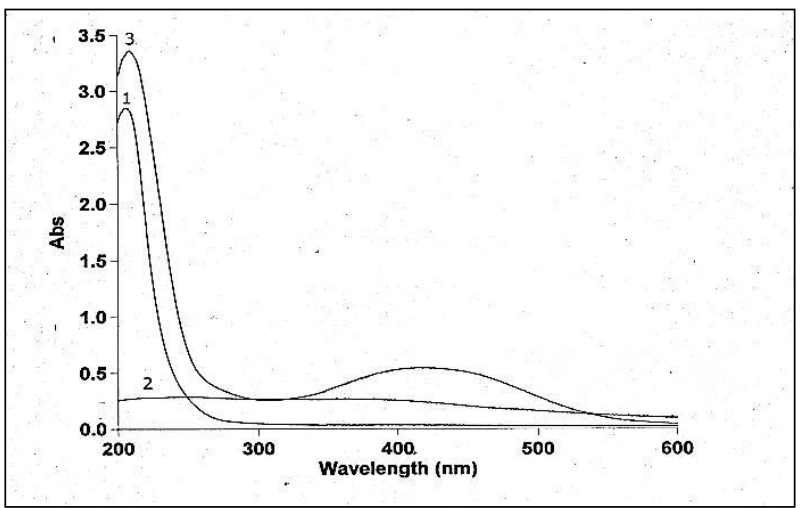

Fig.(2): U.V - Vis spectra 1) Deferoxamine

2) $\mathrm{FeCl}_{2} \cdot \mathrm{XH}_{2} \mathrm{O}$ 3) Iron-Deferoxamine complex.

The selected wavelength was $430 \mathrm{~nm}$ due to the neglecting absorbance of deferoxamine and the minimal contribution of Fe(II). Despite the $\mathrm{Fe}$ (II) small contribution at $430 \mathrm{~nm}$, the complex absorbance was corrected by $\mathrm{Fe}$ (II) subtraction in this wavelength (Acorr.). The Job's plot presented in Fig.(3) indicates that the complex stoichiometry is $\mathrm{M}: \mathrm{L}=1: 1$.This result agrees well with the data of the mass spectrum of the complex. Formation constant of the complex has been calculated by using Job's methods, it found to be $2.0 \times 10^{3}$.

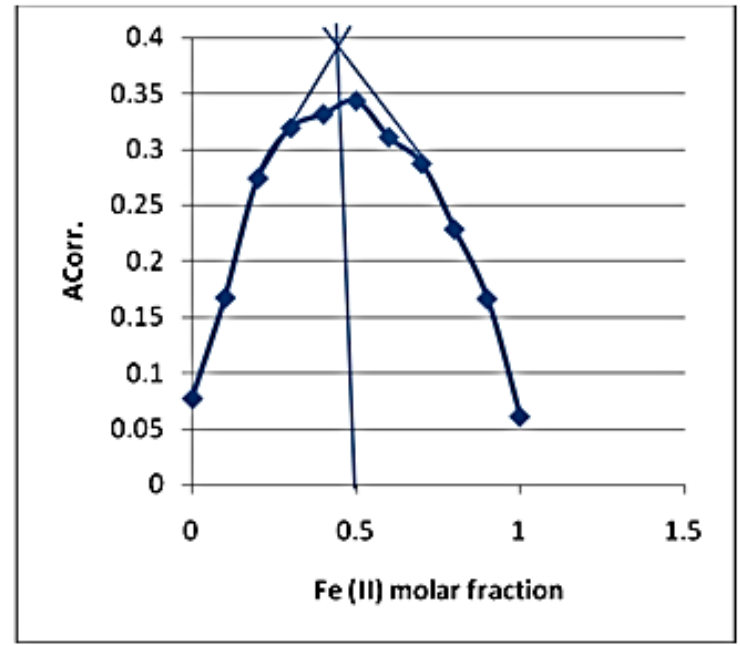

Fig.(3): Job's plot of Iron - Deferoxamine complex.

\section{Molar Ratio}

Aiming to compare the obtained results by continuous variation method, molar ratio method was carried out with the well established spectrophotometric technique.

Series of solutions containing constant concentration of $\mathrm{Fe}(\mathrm{II})\left(10^{-3} \mathrm{M}\right)$ was treated with the same volumes of various concentrations of Deferoxamine. The molar ratio plot presented in (Fig. (4)) indicates that the complex stoichiometry is $M: L=1: 1$. This result corroborates with the result obtained by Continuous variation method.

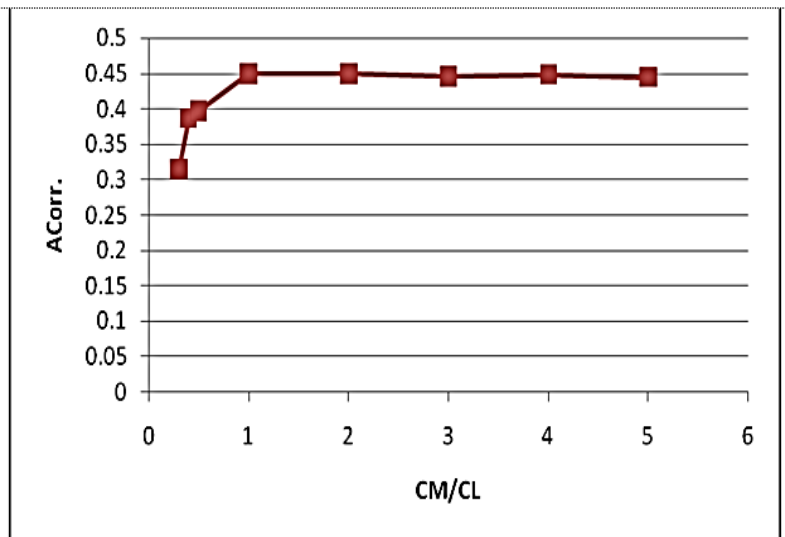

Fig.(4): Molar ratio plot of Iron Deferoxamine complex.

Effect of time on the formation of Iron Deferoxamine complex

In order to study the effect of time on the formation of Iron-Deferoxamine complex, and so to determine the exact time which is deferoxamine needs to remove all of Iron (II) overload, $1 \times 10^{-3} \mathrm{M}$ solution of deferoxamine was mixed with $1 \times 10^{-3} \mathrm{M}$ solution of Iron (II) salt. The absorbances of complex were obtained at $430 \mathrm{~nm}$ and at different time, Fig.(5). This study showed that IronDeferoxamine complex formed immediately and increase with time. So, it can be seen from Fig.(5) that each $1 \times 10^{-3} \mathrm{M}$ of deferoxamine needs $2.5-3 \mathrm{hrs}$ to remove $1 \times 10^{-3} \mathrm{M}$ of Iron (II) overload. 


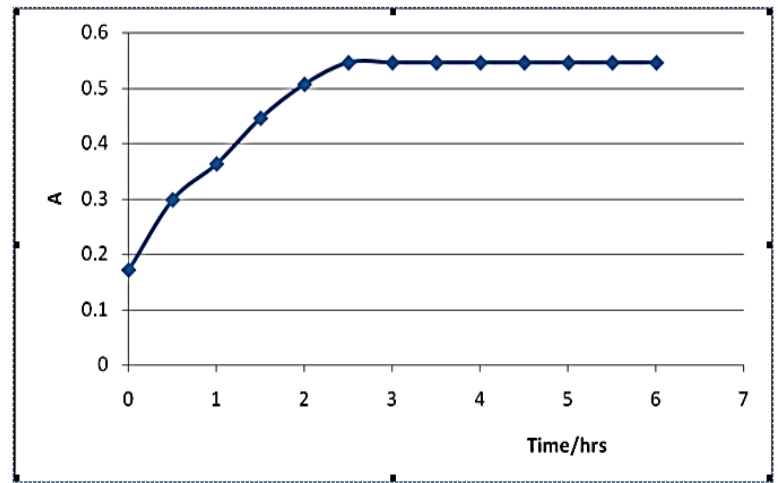

Fig.(5): Effect of time on the formation of Iron - Deferoxamine complex.

\section{Acknowledgments}

We thank Department of Chemistry, College of Sciences, Al-Mustansiriya University for supplying us with some chemicals. Also we wish to thank Dr Adnan I. Mohammed, Department of Chemistry, College of Sciences, University of Karbalaa for his kind help with performing the mass spectrum of Iron - Deferoxamine complex.

\section{References}

[1] Pamela C., Richard, A.; Denise R., Lippincott's Illustrated Reviews: Biochemistry, Lippincott Willams and Wilkins, London, 2008.

[2] U.S. Pat. 4528196, Chelating agents for the treatment of iron overload, 1985.

[3] Ana V. C., Marcelo D. C., Microchemical Journal, 82, 214-219, 2006.

[4] Braun V., Killmann H., Trends in Biochemical Science, 24, 104-109, 1999.

[5] Benite A.,M.,C, Machado S. P., Machado B. C., Química Nova, 25 (6B),1155-1164, 2002.

[6] Marmion C.,J., Griffith D., Nolan K.,B., European Journal of Inorganic Chemistry, 15, 3003-3016, 2004.

[7] Singh S., Hider R.C., Porter J.B., Analytical Biochemistry; 187 (2), 212-219, 1990.

[8] Miller Marvin,. J., Chemical Reviews, 89 (7): 1563-1579, 1989.

[9] Papanikolua G., Tzilianos M., Christakis J., Blood ,105, 4103 - 4105, 2005.

[10] Cotton F.A., Wilkinson G., Gaus P.L., Basic Inorganic Chemistry, 2. ed. John Wiley and Sons, New York, 708 . 1987.

[11] Farkas E., Enyedy E.A., Csóka H., Polyhedron, 18 (18), 2391-3298, 1999.
[12] Enyedy E., A., Pócsi I. Farkas E., Journal of Inorganic Biochemistry; 98 (11) $1957-$ 1966, 2004.

[13] Silverstein R., Webster F., Kiemle D., Spectrophotometric identification of organic compounds, $7^{\text {th }}$ edn. Willy, New York, 2005.

[14] Nakamoto K., Infrared spectra of inorganic and coordination compounds. John Wiley and Sons, New York, 1996.

[15] Lever A., Inorganic electronic spectroscopy. Elesvier Publishing, New York, 1984.

[16] Figgis B., Introduction to ligand field. Mc Graw-Hill Publ. Co. Ltd., New York, 1966.

[17] Sutton D., Electronic spectra of transition metal complex, New York, 1969.

[18] Geary W. J., Coord. Chem. Rev, 7, 81 $122,1971$.

[19] Ostromisslensky I., Ber. Deut. Chem. Ges, 44, 268, 1911.

[20] Job P., Ann. Chim. (Paris), 9, 113, 1928.

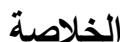

تم تحضير معقد (ديفيروكسامين-الحديد) خارج النظام الحياتي من تفاعل الديفيروكسامين والمستخدم كمادة علاجية

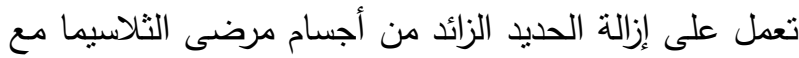

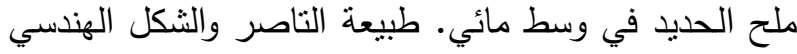
للمعقد تم تحديد من خلال استخدام تقنية الأشعة تحت الحمراء البعيدة ومطايف فوق البنفسية-المرئية ودراسة طيف الكتلة ومحتوى المعقد من عنصر الحديد(III) ودراسـة التوصيلـة المولاريـة وكثفت الدراسـة إن شكل المعقد هـو ثماني السطوح وان الصيغة العامة للمعقد هو [[Fe ${ }^{\mathrm{II}}$ (DEF)]CI2 وطريقة النسب المتغيرة تم التحقق منها في الوسط المائي وكانت النتائج منطابقة مع الحالة الصلبة للمعقد كذلك وكانت النسب بين الايون المركزي والليكند (L: M) يمنل (1:1) وثابت التكوين المقاس للمعقد × 2.0 م $10^{3}$ دراسته أيضا وأظهرت الدراسة إن كل ديفروكسامين تحتاج 2,5-3 ساعة لإزالة 3-10 1010 مولاري من الحديد (II) عن طريق المعقد ألنتاسقي. 